\title{
SUPERVISI PENDIDIKAN DALAM MENINGKATKAN MUTU PEMBELAJARAN PENDIDIKAN AGAMA ISLAM
}

\author{
Nur Hapipa Siregar \\ E-mail : siregarnurhapipah@gmail.com
}

\begin{abstract}
Abstrak
Dalam pembelajaran setiap tempat pendidikan seperti sekolah. Banyak sekarang ini konsep supervisi pendidikan hampir hangus bahkan dilupakan. Sehingga, mutu pembelajaran tersebut juga mulai tidak terlihat. Salah satunya mutu pembelajaran Pemdidikan Agama Islam. Tidak hanya di sekolah, juga di luar sekolah hal ini bisa terjadi. Oleh karena itu, untuk meningkatkan mutu pembelajaran tersebut terutama dalam pembelajaran Pendidikan Agama Islam harus dilaksanakan secara benar dan konsekuen. Sehingga, menciptakan pembelajaran Pendidikan Agama Islam di setiap sekolah semakin matang dan terarah. Dan di sinilah, konsep Supervisi Pendidikan di gunakan untuk meningkatkan mutu pembelajaran Islam.

Sedangkan, pengertian supervisi sendiri yaitu suatu aktivitas pembinaan yang direncanakan untuk membantu para guru dan pegawai sekolah lainnya dalam melakukan pekerjaan secara efektif. Dan pengertian dari Pembelajaran Pendidikan Agama Islam yaitu penekanan kepada sebuah kondisi yang terampil atau mengalami sikap maupun akhlak yang lebih baik dalam kehidupannya yang di konsep sedemikan rupa bagaimana siswa atau peserta didik mengalami perubahan yang baik dalam hidupnya baik kognitif, afektif maupun psikomotrik. Dari pemamparan sebelumnya, bahwa konsep supervisi pendidikan sangat dibutuhkan di zaman sekarang ini untuk meningkatkan mutu pembelajaran Pendidikan Agama Islam di setiap sekolah baik berbasis umum maupun islami.
\end{abstract}

Kata Kunci : Supervisi Pendidikan, Mutu Pembelajaran, Pendidikan Agama Islam. 


\section{PENDAHULUAN}

\section{Latar Belakang Masalah}

Di dalam sebuah pendidikan, sangat diperlukan suasana yang dapat menyeimbangkan antara dunia dan akhirat, cita-cita dan ibadah, wawasan umum dan wawasan islami yang dituangkan dalam Al-Qur'an sebagai pedoman hidup dalam melakukan aktivitas pendidikan apapun. Mau itu dalam bersikap, belajar, memberikan ilmu dan menerimanya. Semua di dasari dengan Al-Qur'an \& Hadits.

Peningkatan Mutu Pendidikan dalam membentuk sebuah kompetensi dasar untuk menciptakan peserta didik menjadi intelektual muslim yang mandiri, diperlukan suatu usaha dari bawah sampai atas yang harus sungguh-sungguh meningkatkan kompetensi dasar yang ada serta mengaplikasikannya dengan cara sederhana dan di pahami oleh peserta didik. Namun untuk menciptakan dan menjalankan konsep tersebut bukanlah sebenarnya hal yang sulit, kalau tidak dimulai dari lingkungan sendiri untuk menciptakannya. Harus dengan interaksi yang kuat antara pemberi dan penerima.

Supervisi Pendidikan bertujuan untuk memberikan kemudahan dalam menjalankan setiap program pendidikan yang sesuai dengan standar yang telah ditetapkan, dengan memperhatikan tercapainya tujuan berdasarkan nilai-nilai agama islam. Tugas tersebut sebagai upaya menjalankan mutu pendidikan dapat dilakukan kepala sekolah sebagai pimpinan yang menjadi ketua dari satuan sebuah pendidikan.

Rumusan Masalah dari artikel ini adalah : (1) Apa pengertian dari Supervisi Pendidikan ? (2) Apa pengertian Pembelajaran Pendidikan Agama Islam ? (3) Bagaimana upaya Supervisi Pendidikan dalam meningkatkan Mutu Pembelajaran Pendidikan Agama Islam?

Tujuan Pembahasan artikel yaitu (1) Meningkatkan pemahaman tentang Supervisi Pendidikan (2) Mengetahui pengertian mutu pendidikan Agama Islam (3) Mengetahui bagaimana upaya Supervisi Pendidikan dalam meningkatkan Mutu Pembelajaran Pendidikan Agama Islam. 


\section{PEMBAHASAN}

\section{Pengertian Supervisi Pendidikan}

Supervisi secara etimologis berasal dari bahasa inggris "to supervise" atau mengawasi. Supervisi juga diartikan sebagai suatu aktivitas pembinaan yang direncanakan untuk membantu para guru dan pegawai sekolah lainnya dalam melakukan pekerjaan secara efektif. Orang yang melaksanakan supervisi disebut juga dengan supervisor. Supervisi disini bukan hanya mengawasi guru atau pegawai dalam menjalankan tugas dengan sebaik-baiknya sesuai dengan instruksi atau ketentuanketentuan yang telah ditetapkan, tetapi juga guru harus berusaha bagaimana cara-cara memperbaik proses belajar mengajar. Tujuan dari Supervisi adalah perbaikan dan perkembangan proses belajar-mengajar secara total, ini berarti bahwa tujuan supervisi tidak hanya untuk memperbaiki mutu mengajar guru, tetapi juga membina pertumbuhan profesi guru dalam arti luas termasuk di dalamnya pengadaan fasilitas yang menunjang kelancaran proses belajar mengajar.

Menurut (Sabandi 2013) Berkembangnya supervisi pendidikan seiring dengan berkembangnya ilmu pengetahuan, teknologi, serta sosial ekonomi daan budaya masyarakat. Supervisi sangat berkembang apabila ada kolaborasi antara supervisor dan guru bersama berinisiatif dan bertanggungjawab dalam meningkatkan kualitas pembelajaran, serta menumbuhkan budaya belajar pada guru untuk meningkatkan kompetensinya.

\section{Pengertian Mutu Pembelajaran Pendidikan Agama Islam}

Mutu dapat diartikan sebagai kadar atau tingkatan dari sesuatu, mutu juga dapat diartikan sebagai tingkat baik buruknya suatu kadar, derajat ataupun taraf, (Kepandaian, kecakapan, dan sebagainya. Mutu pembelajaran ditentukan oleh tiga variable, yaitu budaya atau kebiasaan sekolah, proses belajar mengajar, dan realitas (kenyataan). Dan Pendidikan Agama Islam yaitu bimbingan jasmani dan rohani berdasarkan hukum-hukum agama Islam menuju kepada terbentuknya kepribadian utama menurut ukuran-ukuran Islam. Jadi mutu pembelajaran Pendidikan Agama Islam ialah tingkat baik buruknya suatu kadar jasmani dan rohani berdasarkan 
hukum-hukum agama Islam menuju kepada terbentuknya kepribadaian utama menurut ukuran-ukuran Islam.

\section{Upaya Supervisi Pendidikan Dalam Meningkatkan Mutu Pembelajaran Pendidikan Agama Islam}

Menurut E. Mulyasa (Abdul Hamid Tanjung, 2014) dalam melaksanakan supervisi untuk meningkatkan mutu pembelajaran Pendidikan Agama Islam kepala sekolah harus mampu amelakukan berbagai pengawasan dan pengendalian untuk meningkatkan kinerja tenaga kependidikan. pengawasan dan pengendalian ini bertujuan untuk mencapai tujuan yang di tetapkan sebelmunya yaitu dengan supervisi pendidikan mutu pembelajaran Pendidikan Agama Islam dapat meningkat atau tercapai sesuai yang diharapkan. Selain itu kepala sekolah harus mempunyai kecakapan operasional yang bagus untuk mengendalikan organisasi. Kecakapan operasional menurut Sudarwan Danim dan Suparno dikutip oleh Abdul Hamid Tanjung terdiri atas beberapa hal, diantaranya yaitu :

1. menjadi komunikator dan guru yang baik

2. Mempunyai kecakapan teknis

3. Terampil berhubungan secara manusiawi

4. Mampu dan terampil secara konseptual

5. Mengendalikan rapat dengan baik

6. Menjadi Motivator

7. Sering tampil di tengah komunitas

8. Memiliki humor

9. Dan membina integrasi.

\section{PENUTUP}

\section{Kesimpulan}

Supervisi ialah suatu aktivitas pembinaan yang direncanakan untuk membantu para guru dan pegawai sekolah lainnya dalam melakukan pekerjaan secara efektif. Dalam melaksanakan supervisi untuk meningkatkan mutu pembelajaran Pendidikan 
Agama Islam kepala sekolah harus mampu melakukan berbagai pengawasan dan pengendalian untuk meningkatkan kinerja tenaga kependidikan. Mutu pembelajaran Pendidikan Agama Islam ialah tingkat baik dan buruknya kadar jasmani dan rohani berdasarkan hukum-hukum Agama Islam menuju kepada terbentuknya kepribadian utama menurut ukuran-ukuran Islam.

\section{Saran}

Demikianlah artikel saya ini yang berjudul "Supervisi Pendidikan dalam meningkatkan mutu pembelajaraaaan Pendidikan Agama Islam” semoga artikel ini bermanfaat bagi kita semua. Penulis mengharapkan artikel dapat menambah wawasan dan pengetahuan kita.

\section{Daftar Pustaka}

Hayati, R. M. (2016). Implemenntasi Supervisi Kepala Madrasah dalam Meningkatkan Kinerja Guru di MTs Wali Songo Sukajadi Kecamatan Bumi Ratu Nuban Kabupaten Lampung Tengah . Lampung: IAIN Raden Intan .

Mulati , D. (2016). Strategi Peningkatan Mutu Pembelajaran Pendidikan Agama Islam Dalam Membentuk Akhlak Mulia Peserta Didik Studi Multisitus di MAN 1 Tulungagung dan MAN 3 Tulungagung. Tulungagung: Pasca Sarjana IAIN .

Sabandi, A. (2013). Supervisi Pendidikan Untuk Pengembangan Profesionalitas Guru Berkelanjtutan. Pedagogi, Jurnal Ilmu Pendidikan, XIII(2) http://ejournal.unp.ac.id/index.php/pedagogi/article/view/4275.

Tanjung, A. H. (2014). Pelaksanaan Supervisi Akademik Dalam Meningkatkan Mutu Pembelajaran Pendidikan Agama Islam di SD Negeri Lopian 2 Kecamatan Badiri Kabupaten Tapanuli Tengah. Medan: IAIN Sumatera Utara Medan . 